\title{
Exporting and Innovation Performance: Analysis of the Annual Small Business Survey in the UK.
}

\author{
Dolores Añón Higón, Nigel Driffield ${ }^{\dagger}$, \\ Economics and Strategy Group \\ Aston Business School \\ Aston University \\ Birmingham B4 7ET \\ UK
}

\begin{abstract}
This paper analyses the determinants of the export propensity of UK small and medium-sized enterprises (SMEs) based on the 2004 Annual Small Business Survey. Particular emphasis is placed upon the relationship between innovation activities (distinguishing product from process innovation) and export performance. In general the data suggest that some $17 \%$ of firms within this group sell outside the UK. Businesses that export are also characterized by high levels of innovation activity (43 per cent of exporters innovate in products, 27 per cent innovate in process and 21 per cent innovate in both). When considering product and process innovation independently we find that both impact positively on the decision to export. However, once we consider the interdependence between both innovation activities, we find no robust evidence that process innovation increases the probability to export beyond product innovation.
\end{abstract}

KEWORDS: product innovation, process innovation, export, SME,
endogeneity

JEL CLASSIFICATION: M21, F14, C25

\footnotetext{
${ }^{\dagger}$ We are grateful to Mark Hart, Jim Love and Stephen Roper for comments on an earlier version of this paper. We also acknowledge the financial support of both UKTI and BERR.
} 


\section{Introduction}

The purpose of this paper is to investigate the link between innovation and exporting amongst UK small and medium enterprises (SMEs). This is becoming an ever more important question. Notwithstanding the disadvantages that SMEs face due to their reduced dimension (McDougall et al., 1994), several studies have reported their growing involvement in overseas activities (Bonaccorsi, 1992; Calof, 1994). However, there is still no consensus on the specific mechanisms by which they are able to overcome these disadvantages and succeed in the international markets.

As well as being a contentious in the academic literature, the links between innovation and exporting are important policy questions. From a policy perspective this is becoming more important. Governments around the world are putting more and more resources into trying to boost innovation. To quote from a recent DUIS policy document:

"Britain can only succeed in a rapidly changing world if we develop the skills of our people to the fullest possible extent, carry out world class research and scholarship, and apply both knowledge and skills to create an innovative and competitive economy". Similarly, from BERR rationale for intervention:

"Innovative businesses benefit the UK economy: delivering added value; high quality jobs; successful businesses; better products and services for customers; and new, more environmentally friendly, processes...... In order to deliver Government's overall ambition for wealth creation and productivity growth, sustained business investment in innovation will be necessary.” 
Thus, it is widely accepted that the wealth of a country or region is directly linked to levels of $R \& D$ and innovation ${ }^{1}$. Further, it is becoming recognised in the more general literature, that there are links between exporting activity and innovation. Indeed, our access to these data was prompted by a request from $\mathrm{UKTI}^{1}$ that we examine the Annual Small Business Survey for evidence of exporting behaviour in small firms, and links to innovation. Harris and Li (2005a, 2006a,b) demonstrate, both through a review of the literature and through original empirical work, that links exist between exporting behaviour and innovative behaviour. As with many studies in this area, while Harris and Li(2006b) find evidence to support the hypothesis of exporting leading to innovation, they equally conclude that the situation is far from clear cut. Irrespective however of the ability of researchers to identify clear causal links, this places a further burden or expectation on policy makers. On the one hand, this places more emphasis on policy makers to stimulate exports, and on the other it gives a greater justification for doing so. Most developed countries have a range of schemes aimed at encouraging exporting behaviour in small firms, though the evidence on their success is rather mixed.

There is however a very large literature on the links between innovation and exporting in general, and indeed a recent review paper (Wagner, 2007) cites over 120 papers in this area. More generally, Girma et al (2007) compare the case of the UK and Ireland, highlighting the status of being an exporter as being the important determinant of innovation, and also highlighting the importance of the stage of development of the firm, something ignored often in the economics literature.

Although previous empirical research on the determinants of export performance is high in volume, there are still insufficient studies concerning the internationalisation process of SMEs and the factors that determine their success. In particular, and in contrast to

\footnotetext{
${ }^{1}$ HM Treasury (2003) Productivity in the UK: 4 - The Local Dimension.
} 
studies of larger firms, the importance of technological development and innovation has received much less attention than factors such as the firm's demographic or management characteristics (Nassimbeni, 2001). However, it is generally understood that the traditional model of viewing exporting behaviour, based on life cycle models for example is now redundant, and that firms are becoming exporters much earlier in their development, and at a smaller scale. As such, it is necessary to understand more about the relationships between innovation and exporting amongst SMEs.

This paper presents some empirical analysis of the factors determining the export behaviour of UK SMEs. We offer numerous extensions on the existing literature. First, we focus on small and medium UK businesses. In the literature, as already noted, few works can be found where the unit of analysis is the small or very small firm. Second, we distinguish between the effects of product and process innovation on the export propensity, and, at the same time, we take account of the endogeneity of innovation. Third, while most of the empirical studies analysing the role of innovation on export performance have been based on measures of $R \& D$, few studies have distinguished between product and process innovation. Even when this is the case, process and product innovation are then treated as exogenous or at least as predetermined.

This paper proceeds as follows. The next section provides an overview of previous theoretical and empirical work on the decision to export to motivate their determinants and in particular, on the role of innovation. Section 3 summarizes the main features of the data. Section 4 elaborates on the empirical framework for estimating the impact of the endogenous modes of innovation on export performance of SMEs. The empirical findings are presented in Section 5, and the last section concludes. 


\section{Evidence on exporting and innovation.}

There is a large literature that is concerned with the relationship between exporting behaviour and innovation. Much of this employs data from either bespoke surveys designed for the purpose, or the Community Innovation Survey (CIS), see for example Lefebvre and Lefebvre (2001), Roper and Love (2002), or most recently Lachenmaier and Wößmann (2006) and Roper et al. $(2006)^{2}$. It is noticeable that the focus on this work is on trade flows, or studies of large firms within industries, see for example Braunerhelm (1996), Roberts and Tybout (1997), and Bernard and Jensen (1999, 2001). Much of this finds a link between innovation and exporting, though some papers are more successful than others in identifying a causal relationship. Typically this work is based on manufacturing firms only. From a different perspective, Lages et al. (2004) find similar results, though in the context of a qualitative piece of work than includes analysis of "softer" issues such as branding. Again it is noticeable that the focus for such work is on larger firms.

Various empirical studies have emphasized the role of innovation as an important determinant of export performance (Zhao and Li, 1997; Lefebvre et al., 1998; Roper and Love, 2002). However, evidence based on firm level analysis, and in particular on smaller firms is not as conclusive ${ }^{3}$. Typically, the first problem is in measuring innovation. Kumar and Siddharthan, (1994) for example show that the relationship between innovation and export performance appears weak when innovation is measured exclusively by means of R\&D indicators This has lead to an understanding of the need to measure innovation more carefully than simply through R\&D spend, and the results presented here highlight the importance of this. 
The direction of causality between export and innovation is still an issue of debate in the literature. Traditional product-life-cycle models predict that the causality runs from undertaking innovation activities to exporting. On the other hand, exports may themselves be a cause of innovation activities as predicted by trade models of endogenous growth theories (cf. Grossman and Helpman, 1991). Only few empirical studies in the export literature account explicitly for the potential endogeneity of innovation with respect to exports. In general, these studies use simultaneous equation systems to disentangle the determination of exports in an export equation from the determination of innovation in an innovation equation. This is explained in detail in Maddala (1983), and employed for example in Smith et al. (2002). More recently, Lachenmaier and Wößmann (2006) use the impulses and obstacles reported by the firms as instruments of the actual innovation, which allows them to estimate by two stage least squares the causal relationship between innovation and exporting of German firms.

A literature has developed on the importance of innovation for exporting (or exporting for innovation) within the specific context of small businesses (Rogers, 2004; Yang et al., 2004; and Requena-Silvente, 2005). Many of these studies adopt a similar framework to the one employed here, that is setting up the problem as a model of the decision of a firm to export, and relating that to the variables of interest. These, along with Hellenstein (2005) and Lachenmaier and Wößmann (2006) highlight in a rather piecemeal way the importance of variables such as ownership nationality and use of technology in exporting, and a lot of this borrows from the more general innovation / exporting literature. This builds on work by Roper and Love (2002) and Roper et al (2006) who highlight these issues. More recently, Love et al (2006) and Love et al (2009), building on the work that is very well summarised in Wagner (2007) on the links between exporting, 
innovation and productivity, highlight the importance of nationality, ownership and human capital in explaining the links between exporting and innovation. To the best of our knowledge however these have not been tested in a small business context. Many of the existing studies face severe data limitations. We offer two significant contributions to this literature. Firstly, we seek to control for the endogeneity between innovation and exporting in our analysis, something that is typically not done well in the SME literature. Nguyen et al (2008) offer an important contribution in terms of the links between exporting and innovation for the SME sector in Vietnam. Working on a data set that is of similar construction to ours, ie an official stratified survey. However, while their analysis appears to have very carefully done, Nguyen et al (2008) appear to suffer from a rather limited database, in that they are not able to control for a good deal of heterogeneity in their data, in terms of ownership, age of business, human capital of the management, nationality and use of ICT. This is not necessarily to criticise the work of Nguyen et al (2008) as it may be the case that SMEs in Vietnam are far more homogeneous than in a country like the UK. But for example in the case of the UK, to not distinguish between foreign / domestic ownership when examining exports, or to not include an indicator of ICT use when looking at innovation would severely bias the results in the context of innovation. Nguyen (2008) rely on regional or sectoral dummies to capture differences in for example levels of technolology use between firms, which rather limits some of the inferences with respect to explaining differences in innovation.

The other most obvious difference is the institutional setting of the two studies. While SMEs in all settings face a distinct set of challenges, one can imagine them being very different across these two settings, particularly in the motives for internationalisation. Never the less, Ngyehn et al (2008) offer an important contribution to the modelling of 
the relationship between innovation and exporting where a rich dataset provides a good deal of firm level information, but that is limited to one time period. We therefore adopt a similar methodology, but are able to control for a wider range of firm level factors germane to either innovation or exporting.

As Hollenstein (2005) has pointed out, much of the literature on the technological development of firms is based on the theory, or study of large firms, while the precise nature of the relation between technology and international operations may well be different for small firms ${ }^{4}$. We therefore seek to combine the analytical treatment offered by for example Lachenmaier and Wößmann (2006) with a relatively large sample of SMEs covering a wide range of variables.

The importance of the internationalization of SMEs has additionally being recognized through the relatively new literature on "born globals". This issue has emerged over the past few years in the international business literature (see Knight and Cavusgil, 2004). The analysis of these firms suggests that they become international once they could no longer expand domestically, but that in sectors with low economies of scale, this becomes attractive earlier in the forms development. These firms are characterised by high levels of specialised human capital, as suggested by Knight and Cavusgil (2004), and more managerial vision and a willingness to take risks.

\section{Some initial analysis and data description}

The reports published by Small Business Service (SBS) for $2003^{5}$ and $2004^{6}$ provide an overview of the analysis of the Annual Small Business Survey (ASBS). To quote from the description of the ASBS available from BERR "The Annual Small Business Survey is a telephone survey of several thousand small and medium-sized businesses in the 
UK....The main purpose of the survey is to gauge the needs and concerns of small businesses and identify the barriers that prevent them from fulfilling their potential. The forerunner of the Annual Small Business Survey was the Small Business Service Omnibus survey that also sought the opinions of small businesses and only covered businesses in England.

As the executive summary of the ASBS describes, this survey is designed to collect information on the needs of small businesses, and gauge their major concerns. This is based on a telephone survey of 7505 small businesses in the $\mathrm{UK}^{7}$, ranging from zero to 249 employees. The initial sampling frame is stratified by region, sector and size of business, to reflect the population of firms at the given point in time. The final observations then have weights attached to them to reflect the differences between the final sample and the population, in other words to take account of how representative of a given sector / region a given observation is. Typically, this means that higher weights are attached to smaller firms. This gathers data on a wide range of issues, though the two important questions for this study relate to exporting activity and innovation. Typical of a wide ranging survey such as this, it also gathers a large quantity of firm specific information, relating to region, industry, form of ownership, human capital of the owners and the perceived obstacles to further development. Thus, it provides a relatively large sample size, as well as a more detailed questionnaire than can typically be gathered through academic research.

Regarding the two key variables, the database provides information on whether a firm exports and whether it introduced new product innovations or process innovations. The fundamental questions in the survey for the analysis of exporting activity and innovation activities among small firms are as follows: 
Exporting: Does your business sell outside the UK?

Innovation: Have you introduced new or significantly improved products in the past

12 months?

Have you introduced new or significantly improved processes in the past 12 months?

As our outcome variable, we construct a dummy variable that takes a value of one if the firm sells outside the UK (i.e. exports) and zero if they do not. ${ }^{8}$

\subsection{Summary data from the ASBS.}

This section provides some initial analysis of the breakdown of the exporting and innovation data.

\section{$<$ Table I here >}

The returns are slightly biased towards older, more established firms, and hence overstate the percentage of exporters among SMEs based on the raw data. However, even once weights have been applied, this suggests that some 17 per cent of SMEs in the UK are exporters. Harris and Li (2005b) in a study of firms with more than 10 employees suggest that $26 \%$ of UK firms in 2000 were exporters the difference largely being accounted for by our sample including some very small firms ${ }^{9}$. Table II illustrates that just under 40 per cent of the raw sample who were asked reported carrying out some product innovation, while this declines to just 28 per cent when one allows for the weighting. Process innovation is less common, with 20 per cent of SMEs engaged on it.

\section{<Table II here >}


Table III illustrates in a descriptive sense the relationships between exporting and innovation in our sample. The difference between exporters and non-exporters in terms of innovation activities is remarkable, particularly when referring to product innovation. Over 43 per cent of firms that operate in foreign markets have introduced a product innovation in contrast to only 26 per cent of non-exporters. In a similar way, near 27 percent of exporters (in contrast to 19 per cent of non exporters) conduct process innovation. Figures in Table III also reveal complementarities in innovation activities. Particularly, most SMEs that undertake product innovation do simultaneously process innovation (with just 10 per cent of firms that export undertaking only process innovation).

\section{$<$ Table III here >}

Table IV highlights some similarities in the patterns of innovation and exporting across industries, and also some significant differences. SMEs, in general, report more innovation than they do exporting (the exception being air transport and storage and supporting transport), with much larger differences in the service sector, perhaps not surprisingly. Within sectors, exporting activity is much higher in air transport (64 per cent), storage and supporting transport (42 percent), wholesale (33 per cent) and manufacturing (29 per cent). In contrast, exporting is very low in fishing ( 1 per cent), electricity, gas and water supply ( 3 per cent), land transport ( 5 per cent) and agriculture ( 5 per cent). These results also suggest however that any apparent relationship between innovation and exporting will not be driven solely by inter-industry differences. 
<Table IV here $>$

\subsection{Determinants of Export Performance: The choice of Independent Variables}

The literature concerning the determinants of exporting suggests a grouping of variables into three categories. These determinants can be classified as (a) characteristics of the firm, (b) management factors, which in general refer to entrepreneurial and management characteristics and (c) a group of variables related to firms' environment and which includes the incentives and obstacles in the process of internationalisation (Bonaccorsi, 1992). The following explores in more detail these variables conditional on the information facilitated by the dataset.

(a) Firm Characteristics: In this first group are included those variables related to structural factors of the firm.

-Firm Size: This variable enters as proxy for the availability of resources to overcome the sunk costs associated with entry into foreign markets. The relationship between export propensity and firm size has in general being found positive but non-linear (Roper and Love, 2002) ${ }^{10}$.

-Firm age: The empirical literature provides no consensus with respect to the importance of firm age. Theoretically, a positive relationship may be expected considering that years of accumulated experience may capture "learning by doing" effects (Baldwin and Rafiquzzaman, 1998). However the opposite is expected if younger firms may behave more proactive, flexible and aggressive. Welch and Weidersheim-Paul (1980) report a positive effect of age, while others have ascertained a negative one (Das, 1994). 
- Ownership and Multi-plant effects: Roper and Love (2002) also emphasise the potential benefits of being part of a multi-plant group, finding that, in the UK at least, group-members were likely to have higher export propensity than similar single-plant businesses. Firms belonging to a business group are expected to be more likely to export, since the group allows firms to overcome the problem of lacking resources necessary to export, such as finance, physical or human capital. Moreover, if business group is international, the firm could easier surpass the barriers early mentioned (Roper et al. 2006). In a similar vein, the legal status of the business is often found to impact on business decisions, especially in an international context where exporting may be seen as being more risky.

- Innovation and Technological Variables: Product cycle and technology gap theories of trade suggest that innovation is the driving force behind exports (Vernon, 1966; Krugman, 1979). Innovation is one of the most important variables incorporated to export behaviour analysis, but again, the conclusions about its influence diverge. We use data on the introduction of new products and processes as a proxy for the firm's innovation activities. In general, previous studies have found that product innovation positively affects the probability of export (Nassimbeni, 2001; Basile, 2001; Wakelin 1998; Roper and Love, 2002) and export intensity (Basile, 2001; Roper and Love, 2002) by increasing competitiveness and opening new markets. Studies on process innovation, however, obtain conflicting results: in some cases there is not relationship to export probability (Nassimbeni, 2001), or a positive effect is found on the probability and the propensity (Basile, 2001). As an important control variable, we include ICT use, which is also an important identifying variable, especially in terms of the impacts of innovation. 
(b) Management Factors: According to the empirical literature, one of the main determinants of export behaviour in small firms is entrepreneurial attitude (Cavusgil and Zou, 1994). The following are the variables that we incorporate in our model, given availability in the dataset.

Qualifications: Previous literature in the export marketing field acknowledges the positive link between the educational level of the manager and the degree of export involvement of the firm (Axinn, 1988); with higher educational levels associated with internationalization.

Age of entrepreneur: Several studies observed that younger managers seem to be more export oriented than their older counterparts (Jaffe et al, 1988). Nationality may also be important, and is generally omitted from studies of SMEs. It is reasonable to assume that owners born outside the UK may have a more international perspective than the average UK firm owner.

(c) Business Environment: Miesenbock (1988) highlights the importance of domestic market conditions, and access to credit in explaining exporting behaviour. Surprisingly, this issue is seldom addressed within the small business literature in the context of exporting, though Gumede (2004) highlights the importance of financial constraints faced by firms that are seeking to export. Numerous authors focus on the information constraints that limit exporting behaviour, see for example Rogers (2004) or Kingsley and Malecki (2004) who focus on the importance of networking as well as the innovation process in explaining exporting behaviour. In this line, we control for whether the business has sought advice recently or is member of a trade association. We extend this by including an analysis of the extent to which competition at home hinders the move to exporting, and make use of the particularly important data on the 
ability of firms to raise finance and the extent to which this explains exporting behaviour.

\section{$<$ Table V here >}

\section{The modelling framework}

We present a series of models to examine the relationships between innovation and exporting. First, we present a straightforward analysis of exporting behaviour (model A), taking the innovation decision as predetermined. Second, we generalize and allow for endogeneity of innovation activities using a simultaneous probit model (Model B).

We start with a Probit model (Model A) of the decision to export by SMEs. This procedure consists of estimating a model of what determines whether exporting is undertaken or not:

(1) Export $_{i}^{*}=\lambda$ Innov $_{i}+\alpha X_{i}+\beta N_{i}+\gamma Z_{i}+v_{i}$

with Innovi, the measure for innovation activities, $\mathrm{X}_{\mathrm{i}}$ a vector of firm-specific characteristics (size, ownership, legal status, etc), $\mathrm{N}_{\mathrm{i}}$ is a vector of the owner characteristics and $\mathrm{Z}_{\mathrm{i}}$, a vector of environmental factors (including obstacles to competition and industry, regional effects, etc). The error term $v_{i}$ is assumed to be iid $\sim \mathrm{N}\left(0 ; \sigma_{\mathrm{u}}\right)$. The export measure Export ${ }^{*}$ cannot be observed completely. The observed model is given by the binary choice: 
(2) $\quad$ Export $_{i} \begin{cases}=1 & \text { if } \text { Export }_{i}^{*}>0 \\ =0 & \text { if Export }\end{cases}$

One limiting factor, common to most studies on small firms, is that we have only a cross section of data, so are unable to include lagged variables directly. To take into account the endogeneity of exporting and innovation decisions we consider a simultaneous estimation method in the line of previous studies (Zhao and Li, 1997 and Smith et al, 2002). One way to estimate the simultaneous model is to regress each endogenous variable on the entire set of assumed exogenous variables and construct the predicted variables as instruments (see Maddala, 1983). In the second stage, the innovation variables are then replaced with these instruments in the export equation. This generates unbiased estimates of the impact of innovation on exports. Similar simultaneous approaches have been employed in several empirical studies treating innovation and exports as inextricably interdependent (Hughes, 1986; Zhao and Li, 1997; Smith et. al., 2002; Cassiman and Martinez-Ros, 2006; and Lachenmaier and Wößmann, 2006). We therefore model the probability of exporting, and the probability of innovation, as both independent and dependent probabilities, and present the results across the range of estimators.

In choosing the likely determinants of exporting propensity, we include those variables that have been shown to be important in the traditional and modern literature of international trade and SMEs performance, details of these are given in Table $\mathrm{V}^{11}$. In addition, the full set of industries and regions were included, to allow for these effects, as suggested by section 3 .

\section{Empirical Results}


As baseline comparison, the first two columns in Table VI (Model A) report the results of the determinants of export propensity without considering the problem of endogeneity. The coefficients reported $(\partial \hat{p} / \partial x)$ are the marginal effects, (i.e. the ceteris paribus change in the probability of an establishment exporting with respect to a change in each determining variable). Among the more fundamental determinants of the probability of exporting in UK SMEs is the decision to undertake product innovation. When treated exogenously, product innovation is associated with 11.3 per cent higher probability of selling internationally (cet. par.)

Other variables that affect the probability of exporting are:

The age of the business, with businesses trading for less than four years 16 per cent less likely to export (cet. par.).

ICT users are some 15.8 percent more likely to undertake international activities. Ownership, companies with a majority of UK-born directors or mangers are 14.6 per cent less likely to export (cet. par.) than those enterprises with a majority of foreignborn directors or managers. Family businesses are 8.2 per cent less likely to be exporters, and sole proprietors and partnerships are 16 per cent less likely to export than limited companies, even after allowing for industry differences.

Perhaps surprisingly, the size of the establishment, however, was not significantly important in determining whether any exporting took place; vis-à-vis the baseline group (establishments employing none employees).

\section{<Table VI here >}


The entrepreneur's specific characteristics in terms of education or age, proved not to be significant in determining the probability to export. On the other hand, those SMEs facing obstacles to competition were 9 per cent more likely to export. Industry and regional effects do not seem to have much significant impact in determining the probability to export of SMEs after controlling for other effects. Only those businesses belonging to the construction sector were $21 \%$ were found to less likely to export vis-àvis the sectors not explicitly listed (i.e. agriculture, hunting and forestry). None of the other variables entered proved to be significant barriers to entry into export markets.

As outlined above, it is important to take into consideration the simultaneity of exporting and innovation decisions. Tables VI and VII report the simultaneous estimation results for the exporting and product and process innovation respectively. Model B in Table VI present the results from the simultaneous equations, including the results for the innovation equation. Comparing the bivariate results with the univariate results from Model A shows that the changes in the estimated coefficients are very small and the significance is unaffected, with the exception of the innovation variable. The results suggest that those businesses undertaking product innovation are 48 per cent more likely to export, and that the univariate estimation significantly under-estimates the importance of product innovation in explaining exporting propensity.

Table VII replicates the analysis presented in table VI, but focuses on process innovation. Again, process innovation is strongly related to exporting, across all the models and across types of estimation. Model $\mathrm{B}$ in particular shows that different factors explain exporting and process innovation, with only ICT user significant in both equations. 
Across these models, the other variables that affect the probability of exporting are the age of the business, the nature of ownership, with both partnerships and family businesses less likely to be exporters, even allowing for industry effects. Finally obstacles to competition proved to be significant in determining the likelihood to export; suggesting that exporting is indeed undertaken by some SMEs where they feel further domestic development is restricted.

\section{Table VII here}

Table III highlighted the existence of important complementarities regarding the innovation activities of UK SMEs. Particularly, it was observed that the majority of companies undertaking product innovation were simultaneously introducing new processes. Given this, and the fact that the innovation variable is dichotomous, it is possible that the results presented in Table VII for process innovation could be picking up the effect of these complementarities, and in particular the impact of product innovation on exporting. We therefore extend the analysis presented in table VII, by determining the relative importance of product and process innovation in explaining the

probability of a firm being an exporter. These results suggest that once one controls for the effect of product innovation, there is no significant additional effect for process innovation. The estimated coefficient on product innovation significantly increases when using the simultaneous approach (Model B), pointing possibly to the importance of endogeneity. Other control variables remain statistically significant. Particularly age of firm, ownership variables, ICT use, and obstacle to competition appear to influence the decision to enter in foreign markets. 


\section{<Table VIII here >}

\subsection{Modelling the Impact of Internationalisation on Innovation}

In the previous section, innovation features as a determinant of the probability to export. However, we also know that businesses will be motivated to undertake innovation because of their (potential) involvement in selling abroad. It is expected that in order to break down the barriers to export, firms must increase their performance and this is likely to include innovation activities. Thus the probability to innovate might in part be explained by exporting.

To account for the potential endogeneity of the export variable in the innovation equation we proceed by adopting a two stage procedure as in the previous section. In the first stage we regress the export variable on the set of assumed exogenous variables and construct the predicted variables as instruments. In the second stage, the export variable is replaced with these instruments in the innovation equation.

\section{$<$ Table IX here $>$}

Table IX presents some further analysis based on the probit and simultaneous models, seeking to determine the effect that being an exporter has on product innovation. This effectively testing for the reverse of causality implied by table VI, that is exporting causing innovation rather than innovation causing exporting. In this case, the simple probit suggests that indeed product innovation is related to exporting. However, once we correct for the endogeneity problem, there is no significant effect of exporting on the probability of introducing new products. This suggests that once we allow for the fact 
that innovation causes exporting, then any apparent effect of exporting increasing the probability of product innovation vanishes.

The results in Table IX suggest that amongst small firms, size is important in explaining the probability of product innovation. Small firms (with more than 10 employees) and medium firms (with more than 50 employees) are significantly more innovative. Other factors that impact on the probability to introduce a product innovation refer to business strategies, particularly with the decision to reinvest generated profits and the decision to introduce new products as a strategy to grow.

\section{Conclusions}

This paper analyses of the relationships between innovation and export behaviour in UK SMEs. Many of the theoretical or conceptual predictions in this area suggest that exporting and innovation are mutually dependent. In contrast therefore to much of the SME literature in this area, but inline with the more general literature, it is crucial that the estimation procedure takes account of this. The optimal empirical model must integrate innovation as well as exporting in order to estimate the factors affecting the export decision by SMEs. In addition, the results have shown that besides factors such as firm characteristics, owner characteristics and other firm-specific factors controlling for risks should be considered highly important for the export performance of small and medium businesses.

One of the objectives of this paper was to provide new empirical insights into the role of product versus process innovation on the decision to export. Either of these modes of innovation has been hypothesized to affect firm-level productivity in previous 
theoretical work. A smaller body of theoretical research even pointed to the differential impact of these two types of innovation on a firm's export propensity. In common with the findings of Lachenmaier and Wößmann (2006), we find that there is indeed an apparent causal relationship between product innovation and exports, in that product innovation leads to exporting. However, the apparent causal relationship leading from exporting to innovation is not robust to the correction for endogeneity. Thus, one can conclude for small and medium firms at least, that innovation causes exporting rather than the reverse. These results are robust to the inclusion of a wide range of firm specific factors, with a greater range of such variables included than in most previous studies. These results are also robust to industry level differences, and other indicators of innovation such as the use of ICT. We find also that ownership variables and the age of the firm affect significantly the probability to export.

Process innovation however seems to have little impact on the exporting decision. Overall, the results point to the importance of product innovation relative to process innovation, at least in terms of the internationalisation of firms. In comparison, there is no evidence that process innovation enhances the probability of SMEs to export beyond the impact of product innovation. We believe that these results have immediate policy relevance. Indeed they confirm the importance of innovation policies that aim at providing incentives for small firms to engage them in product innovation, which we have shown is a key factor in helping them to overcome barriers to entry into foreign markets that they may face due to its size. 


\section{Notes}

\footnotetext{
${ }^{1}$ UK Trade and Investment

${ }^{2}$ Much of the literature in this area is discussed in the review by Harris and Li (2005a).

${ }^{3}$ Wakelin (1998), for instance, found negative effects of R\&D activities on export behaviour in certain sectors.

${ }^{4}$ For further discussion of this see Lautanen (2000).

${ }^{5}$ Atkinson, J. and Hurstfield, J. (2003) Small Business Service Annual Survey of Small Businesses: UK 2003, Institute of Employment Studies (IES): Brighton. IES (2003) Small Business Service Annual Survey of Small Businesses: UK 2003. Additional Analysis, IES: Brighton. (Plus an Executive Summary published by SBS.)

${ }^{6}$ SBS (2004) Annual Small Business Survey: Executive Summary, SBS: Sheffield. A good deal more information on the ASBS, including the full 78 page questionnaire is available from:

http://www.berr.gov.uk/whatwedo/enterprise/enterprisesmes/research-and-statistics/research-evaluation/businesssurveys/page38370.html There is also a 249 page report summarising the key features of the data.

${ }^{7}$ It is also possible to acquire a full copy of the questionnaire from the BERR website given above.

${ }^{8}$ While all firms are questioned about their international activities, only 50 percent of them were randomly surveyed on innovation, though weights to allow for this are incorporated in the data set. In common with most stratified samples, weights are included with the data, to allow for differences between the original stratified sample and the final data, as well as for different subsamples being targeted with certain questions.

${ }^{9}$ Harris and Li (2005b) additionally report that nearly 44 per cent of UK manufacturing firms exported while only 15.6 per cent of service firms did so.

${ }^{10}$ The findings of Bernard and Jensen (1999) suggest that large and strong plants/firms tend to become exporters, rather than exporting enhancing performance.

${ }^{11}$ We also experimented with other variables that sought to measure the 'barriers to business success' but all variables were insignificant.
}

\section{References}

Axinn, C.N., 1988, 'Export Performance: Do Managerial Perceptions Make a Difference?', International Marketing Review, 53, 61-71.

Baldwin, J. and M. Rafiquzzaman, 1998, 'The Effect of Technology and Trade on Wage Differentials between Non-production and Production Workers in Canadian Manufacturing,' Statistics Canada, Analytical Studies Branch, Research Paper No. 98.

Basile, R., 2001, 'Export Behaviour of Italian Manufacturing Firms over the Nineties: The Role of Innovation', Research Policy, 308, 1185-1201.

Bernard, A. and J.B. Jensen, 1999, 'Exceptional Exporter Performance: Cause, Effect or Both?', Journal of International Economics, 47,1-25.

Bernard, A., and J.B Jensen, 2001, 'Why Some Firms Export?', NBER Working Paper No. 8349.

Braunerhjelm, P., 1996, 'The Relation between Firm Specific Intangibles and Exports,' Economic Letters, 53, 213-219.

Bonaccorsi, A., 1992, 'On the Relationship between Firm Size and Export Intensity', Journal of International Business Studies, 23, 605-635

Calof, J., 1994, 'The Relationship between Firm Size and Export Behaviour Revisited', Journal of International Business Studies, 25, 367-387. 
Cassiman, B. and E. Martinez-Ros, 2006, 'Product Innovation and Exports: Evidence from Spanish Manufacturing'. IESE Working Paper.

Cavusgil S.T. and S. Zou, 1994, 'Marketing Strategy-Performance Relationship: An Investigation of The Empirical Link In Export Market Ventures', Journal of Marketing, 58, $1-21$.

Das, M., 1994, "Successful And Unsuccessful Exporters From Developing Countries: Some Preliminary Findings", European Journal of Marketing, 28 (12), 19-33. Girma, Gorg and Hanley (2007) 'R\&D and exporting: A comparison of British and Irish firms', Research Paper 2007/18, GEP, University of Nottingham.

Grossman, G. and E. Helpman, 1991, Innovation and Growth in the Global Economy, Cambridge: MIT Press.

Gumede, V., 2004, 'Export Propensities of Small And Medium Manufacturing Enterprises In South Africa', Small Business Economics, 22, 379-389.

Harris, R.I.D. and Q.C. Li, 2005a, Establishment Level Empirical Study of Links Between Exporting, Innovation, and Productivity. Report for UKTI.

Harris, R.I.D. and Q.C. Li, 2005b, Review of the Literature: The Role of International Trade and Investment in Business Growth and Development. Report for UKTI.

Harris, R.I.D. and Li, Q.C. (2006a) Review of the Literature: Causal Links between Innovation and International Trade and Investment. Report to UKTI, April 2006

Harris, R.I.D. and Li, Q. C (2006b) Establishment Level Empirical Study of Links between Exporting, Innovation and Productivity - CIS 4. Report to UK Trade and Investment.

Hollenstein, H., 2005, 'Determinants of International Activities: Are SMEs Different?', Small Business Economics, 24, 431-450.

Hughes, K., 1986, Exports and Technology, Cambridge: Cambridge University Press. Jaffe, E.D., Pasternak, H. and I. Nebenzahl, 1988, 'The Export Behaviour of Small Israeli Manufacturers', Journal of Global Marketing, 22, 27-49.

Kingsley, G. and E.J. Malecki, 2004, 'Networking for Competitiveness', Small Business Economics, 23, 71-84.

Knight, G.A. and S.T. Cavusgil, 2004, 'Innovation, organizational capabilities, and the born-global firm', Journal of International Business Studies, 35, 124-141

Krugman P.R., 1979, 'Increasing Returns, Monopolistic Competition and International Trade', Journal of International Economics, 94, 469-479.

Kumar, N. and N. Siddharthan, 1994, 'Technology, Firm Size and Export Behaviour in Developing Countries: The Case of Indian Enterprises', Journal of Development Studies 31, 289-309.

Lachenmaier, S. and L. Wößmann, 2006, 'Does Innovation Cause Exports? Evidence from Exogenous Innovation Impulses and Obstacles using German Micro Data', Oxford Economics Papers, 582, 317-350. 
Lages, L.F., C. Lages, and C.R. Lages, 2004, 'European Perspectives on Export Performance Determinants: An Exploratory Study', FEUNL Working Paper No. 444.

Lautanen, T., 2000, 'Modelling Small Firms' Decisions to Export- Evidence From Manufacturing Firms in Finland', Small Business Economics, 14,107-124.

Lefebvre, E., L.A. Lefebvre and M. Bourgault, 1998, 'R\&D-related Capabilities as Determinants of Export Performance', Small Business Economics, 10, 365-377

Lefebvre, E. and L.A. Lefebvre, 2001, 'Innovative Capabilities as Determinants of Export Performance and Behaviour: A Longitudinal Study of Manufacturing SMEs', in

Kleinknecht, A. and P. Monhen (eds.), Innovation and Firm Performance: Econometric Explorations of Survey Data, Palgrave MacMillan Press, London.

Maddala, G.S., 1983, Limited-Dependent and Qualitative Variables in Econometrics, Cambridge, Massachusetts: Cambridge University Press.

McDougall, P., S. Shane and B. Oviatt, 1994, 'Explaining the Formation of International Ventures: The Limits of Theories from International Business Research', in W. Bygrave, S. Birley, N. Churchill, E. Gatewood, F. Hoy, R. Keeley and W. Wetzel, (eds.), Frontiers of Entrepreneurship Research, Babson College: Massachusetts, pp. 535-549.

Miesenbock, K.J., 1988, "Small Businesses and Exporting: A Literature Review", International Small Business Journal, 6(1), 42-61.

Nassimbeni, G., 2001, 'Technology, Innovation Capacity, and the Export Attitude of Small Manufacturing Firms: a Logit/Tobit Model', Research Policy, 30, 245-262.

Requena-Silvente, F., 2005, 'The Decision to Enter and Exit Foreign Markets: Evidence from UK SMEs', Small Business Economics, 25, 237-253.

Roberts, M. and J.R. Tybout, 1997, 'The Decision to Export in Colombia: An Empirical Model of Entry with Sunk Costs', American Economic Review, 87, 545-564.

Rogers, M., 2004, 'Networks, Firm Size and Innovation', Small Business Economics, 22, 141-153.

Roper, S. and J.H. Love, 2002 'Innovation and Export Performance: Evidence from UK and German Manufacturing Plants', Research Policy, 31, 1087-1102.

Roper S., J.H. Love and D. Anon Higon, 2006, 'The Determinants of Export Performance: Evidence for Manufacturing Plants in Ireland and Northern Ireland', Scottish Journal of Political Economy, 53, 586-615.

Smith, V., E.S. Madsen, M. Dilling-Hansen, 2002, Export Performance and Investment in R\&D, Aarhus: The Danish Institute for Studies in Research and Research Policy, Working Paper 2002/4.

Vernon, R., 1966, 'International Investment and International Trade in the Product Cycle', Quarterly Journal of Economics, 80, 190-207.

Yang, C.H., J.R. Chen, and W.B. Chuang, 2004, 'Technology and Export Decision', Small Business Economics, 22, 349-364.

Wagner, J. (2007) "Exports and Productivity: A Survey of the Evidence from Firm-level Data," The World Economy, Blackwell Publishing, vol. 30(1), pages 60-82, 
Wakelin, K., 1998, 'Innovation and Export Behaviour at the Firm Level', Research Policy, 267, 829-841.

Welch L.S. and F. Wiedersheim-Paul, 1980, 'Initial Exports - a Marketing Failure?', Journal of Management Studies, 17, 334-344.

Zhao, H. and H. Li, 1997, 'R\&D and Exports: An Empirical Analysis of Chinese Manufacturing Firms', Journal of High Technology Management Research, 8(1), 89105.

TABLE I

Export Data

\begin{tabular}{lrrrr}
\hline & \multicolumn{2}{c}{ Unweighted } & Weighted \\
\cline { 2 - 5 } & Frequency & Percent (\%) & Frequency & Percent (\%) \\
\hline Yes & 1718 & 22.9 & 1302 & 17.3 \\
No & 5765 & 76.8 & 6189 & 82.5 \\
Don't know & 22 & .3 & 14 & .2 \\
Total & 7505 & 100.0 & 7505 & 100.0 \\
\hline
\end{tabular}

Source: Author's calculation using the ASBS 2004 dataset.

TABLE II

Innovation Data

\begin{tabular}{|c|c|c|c|c|c|c|}
\hline & \multicolumn{3}{|c|}{ Unweighted Data } & \multicolumn{3}{|c|}{ Weighted Data } \\
\hline & Frequencies & Percentage & $\begin{array}{l}\text { Percentage } \\
\text { (excluding DKs) }\end{array}$ & Frequencies & Percentage & $\begin{array}{l}\text { Percentage } \\
\text { (excluding DKs) }\end{array}$ \\
\hline Product & 1390 & $19 \%$ & $38 \%$ & 1056 & $14 \%$ & $28 \%$ \\
\hline None & 2313 & $31 \%$ & $62 \%$ & 2663 & $35 \%$ & $72 \%$ \\
\hline $\mathrm{DK} / \mathrm{NA}$ & 3802 & $51 \%$ & - & 3786 & $50 \%$ & - \\
\hline Total & 7505 & $100 \%$ & $100 \%$ & 7505 & $100 \%$ & $100 \%$ \\
\hline Process & 1048 & $14 \%$ & $28 \%$ & 753 & $10 \%$ & $20 \%$ \\
\hline None & 2667 & $36 \%$ & $72 \%$ & 2968 & $40 \%$ & $80 \%$ \\
\hline DK/NA & 3790 & $50 \%$ & - & 3784 & $50 \%$ & - \\
\hline Total & 7505 & $100 \%$ & $100 \%$ & 7505 & $100 \%$ & $100 \%$ \\
\hline
\end{tabular}

Source: Author's calculation using the ASBS 2004 dataset.

TABLE III 


\begin{tabular}{|c|c|c|c|}
\hline \multicolumn{4}{|c|}{ Exporting and Innovation in UK SMEs (figures are percentages, \%) } \\
\hline & Exporters & Non-Exporters & Total \\
\hline Product Innovation & 43.3 & 25.6 & 28.4 \\
\hline Process Innovation & 26.9 & 18.9 & 20.3 \\
\hline Either Product or Process & 47.7 & 30.7 & 33.6 \\
\hline Both Product and Process & 20.9 & 13.5 & 14.7 \\
\hline Only Prod. Innovation & 28.4 & 14.6 & 16.7 \\
\hline Only Proc. Innovation & 10.2 & 7.1 & 7.5 \\
\hline
\end{tabular}

Source: Author's calculation using weighted data from the ASBS 2004 dataset

TABLE IV:

Exporting and innovation in UK SMEs, by industry (figures are percentages, \%)

\begin{tabular}{llll}
\hline Industry & Export (\%) & $\begin{array}{l}\text { Product } \\
\text { innovation (\%) }\end{array}$ & $\begin{array}{l}\text { Process } \\
\text { innovation (\%) }\end{array}$ \\
\hline Agriculture, Hunting and Forestry & 5 & 17 & 9 \\
Fishing & 1 & 15 & 9 \\
Mining and Quarrying & 19 & 28 & 16 \\
Manufacturing & 29 & 32 & 28 \\
Electricity, Gas and Water Supply & 3 & 96 & 3 \\
Construction & 6 & 22 & 17 \\
Retail Trade & 15 & 38 & 19 \\
Wholesale Trade and Commission Trade & 33 & 23 & 14 \\
Motor Vehicles and Motorcycles & 14 & 13 & 21 \\
Hotels and Restaurants & 14 & 27 & 19 \\
Land Transport, transport via Pipelines & 5 & 25 & 9 \\
Water Transport & 13 & 100 & 100 \\
Air Transport & 64 & 26 & 10 \\
Storage and Supporting Transport Activities & 42 & 12 & 14 \\
Post, Storage and Communication & 16 & 19 & 12 \\
Financial Services & 16 & 23 & 22 \\
Real Estate, Renting and Business Activities & 22 & 31 & 21 \\
Education & 8 & 30 & 34 \\
Health and Social Work & 6 & 43 & 31
\end{tabular}




\begin{tabular}{llll}
\hline Other Services & 16 & 36 & 28 \\
\hline
\end{tabular}

Source: Author's calculation using weighted data from the ASBS 2004 dataset

TABLE V

Variable Definitions used in the ASBS dataset for 2004

\begin{tabular}{|c|c|}
\hline Variable & Definitions \\
\hline Export & Whether the business sold goods and services outside the UK (coded 1) or not \\
\hline Process & Whether the business had introduced any process innovation as defined in the text \\
\hline Innovation & (coded 1$)$ or not \\
\hline Product & Whether the business had introduced any product innovation as defined in the text \\
\hline Innovation & $($ coded 1$)$ or not \\
\hline \multicolumn{2}{|c|}{ Firm Characteristics } \\
\hline Size & $\begin{array}{l}\text { Business size broken down into size-bands (none }=0, \text { micro }=1-9, \text { small }=10-49 \text {, } \\
\text { medium }=50-250 \text { employees) }\end{array}$ \\
\hline New Business & Dummy variable $=1$ if business has been trading for less than 4 years \\
\hline Multi plant & Dummy coded 1 when business operates in more than 1 site \\
\hline UK-owned & Dummy coded 1 if business $i$ has a majority of directors born in UK \\
\hline Legal status & Legal status of the business (company $=1$, partnership $=2$, sole proprietor $=3$ ) \\
\hline Family-owned & Dummy coded 1 if business $i$ is family owned \\
\hline ICT-user & Dummy coded 1 if business $i$ uses ICT \\
\hline \multicolumn{2}{|c|}{ Owner Characteristics } \\
\hline Owner +46 & Dummy coded 1 if the owner is older than 46 \\
\hline Gender Majority & Dummy coded 1 if there is a majority of male managers or directors \\
\hline Qualifications & $\begin{array}{l}\text { Highest degree attained (other }=1 \text {, A-level or GCSE's or equivalent=2, Higher } \\
\text { degree }=3 \text { ) }\end{array}$ \\
\hline \multicolumn{2}{|l|}{ Business Strategy } \\
\hline Networker & $\begin{array}{l}\text { Dummy coded } 1 \text { if business has sought external advice or member of a trade } \\
\text { association as proxy for networker/isolationist }\end{array}$ \\
\hline
\end{tabular}




\begin{tabular}{l|l|}
\hline BS_Newprod & Dummy coded 1 if business plans to introduce new products as strategy to grow \\
BS_Reinvest & Dummy coded 1 if business plans to reinvest any profit made \\
Business Environment \\
\begin{tabular}{l|l} 
Obs_fin & $\begin{array}{l}\text { Dummy coded } 1 \text { if major obstacle for the business is finance } \\
\text { Obs_comp }\end{array}$ \\
Dummy coded 1 if major obstacle for the business is competition
\end{tabular} \\
$\begin{array}{l}\text { Industry } \\
\text { Region }\end{array}$ & Business industry (1=primary, 2=manufacturing, 3=construction, 5=services) \\
\hline
\end{tabular}

\section{TABLE VI}

Determinants of UK SME's Export Behaviour and the role of Product Innovation

\begin{tabular}{|c|c|c|c|c|c|c|}
\hline & \multirow{2}{*}{\multicolumn{2}{|c|}{\begin{tabular}{|c|} 
Model A \\
Probit
\end{tabular}}} & \multicolumn{4}{|c|}{ Model B } \\
\hline & & & \multicolumn{4}{|c|}{ 2-Stage Estimation } \\
\hline \multirow[t]{2}{*}{ Dependent Var. } & \multicolumn{2}{|l|}{ Export } & \multicolumn{2}{|l|}{ Export } & \multicolumn{2}{|c|}{ Prod Innovation } \\
\hline & $\partial \hat{p} / \partial x$ & Std.err. & $\partial \hat{p} / \partial x$ & Std.err. & $\partial \hat{p} / \partial x$ & Std.err. \\
\hline Prod. Innovation & $0.113^{* * *}$ & $(0.034)$ & $0.487 * * *$ & $(0.137)$ & & \\
\hline \multicolumn{7}{|c|}{ Firm Characteristics } \\
\hline Micro (1/9) & 0.005 & $(0.052)$ & -0.052 & $(0.049)$ & $0.143 * *$ & $(0.044)$ \\
\hline Small (10/49) & -0.009 & $(0.059)$ & -0.066 & $(0.059)$ & $0.167 * * *$ & $(0.050)$ \\
\hline Medium(50/250) & 0.057 & $(0.064)$ & -0.007 & $(0.066)$ & $0.181 * *$ & $(0.058)$ \\
\hline Multiplant & -0.008 & $(0.037)$ & $-0.144 * *$ & $(0.056)$ & & \\
\hline New-business & $-0.162 * * *$ & $(0.049)$ & $-0.274 * * *$ & -0.052 & & \\
\hline UK-owned & $-0.146^{* *}$ & $(0.055)$ & $-0.129 *$ & $(0.056)$ & -0.067 & $(0.055)$ \\
\hline ICT user & $0.158^{*}$ & $(0.073)$ & $0.167^{*}$ & $(0.071)$ & & \\
\hline Family-Bus & $-0.082 *$ & $(0.035)$ & $-0.087^{*}$ & $(0.035)$ & 0.026 & $(0.035)$ \\
\hline Partnership & $-0.162 * * *$ & $(0.037)$ & $-0.155 * * *$ & $(0.037)$ & -0.060 & $(0.052)$ \\
\hline Sole proprietor & $-0.162 * *$ & $(0.053)$ & $-0.163 * *$ & $(0.050)$ & 0.017 & $(0.056)$ \\
\hline \multicolumn{7}{|c|}{ Owner Characteristics } \\
\hline Age $>46$ & & & & & 0.015 & $(0.035)$ \\
\hline A-lev. or GCSE's & 0.014 & $(0.075)$ & 0.048 & $(0.047)$ & 0.037 & $(0.045)$ \\
\hline Higher Degree & 0.056 & $(0.047)$ & 0.066 & $(0.041)$ & 0.033 & $(0.042)$ \\
\hline \multicolumn{7}{|l|}{ Strategic Decisions } \\
\hline Net-worker & -0.019 & $(0.034)$ & -0.006 & $(0.034)$ & & \\
\hline BS_Reinvest & & & & & $0.094 *$ & $(0.041)$ \\
\hline BS_new products & & & & & $0.258 * * *$ & $(0.036)$ \\
\hline \multicolumn{7}{|c|}{ Business Environment } \\
\hline Comp_obst & $0.093 *$ & $(0.039)$ & $0.090^{*}$ & $(0.039)$ & & \\
\hline Finance obst & & & & & $0.370 * * *$ & -0.092 \\
\hline
\end{tabular}




\begin{tabular}{ll|ll}
\hline Industry Effects & Yes & Yes & Yes \\
\hline Regional Effects & Yes & Yes & Yes \\
\hline Log-L & -1115.63 & -1113.49 & -1825.01 \\
Observations & 2163 & 2163 & 2918 \\
\hline
\end{tabular}

Notes: weighted regression was used with ASBS data. For variable definitions, see Table V. $* * *$ significant at $1 \%$-level, $* *$ significant at 5\%-level, *significant at $10 \%$-level, standard errors in parentheses. Regional and industry dummies included but not reported.

TABLE VII

The Impact of Process Innovation on Export Decision of UK SMEs

\begin{tabular}{|c|c|c|c|c|c|c|}
\hline \multicolumn{3}{|c|}{ Model A } & \multicolumn{4}{|l|}{ Model B } \\
\hline & \multicolumn{2}{|l|}{ Probit } & \multicolumn{4}{|c|}{ 2-Stage Estimation } \\
\hline \multirow[t]{2}{*}{ Dependent var. } & \multicolumn{2}{|l|}{ Export } & Export & & \multicolumn{2}{|c|}{ Process Innovation } \\
\hline & $\partial \hat{p} / \partial x$ & Std.err. & $\partial \hat{p} / \partial x$ & Std.err. & $\partial \hat{p} / \partial x$ & Std.err. \\
\hline $\begin{array}{l}\text { Process } \\
\text { Innovation }\end{array}$ & $0.097 * *$ & $(0.035)$ & $0.490 * *$ & $(0.154)$ & & \\
\hline \multicolumn{7}{|l|}{ Firm Characteristics } \\
\hline Micro (1-9) & 0.009 & $(0.052)$ & -0.036 & $(0.050)$ & $0.125^{*}$ & $(0.049)$ \\
\hline Small (10-49) & -0.007 & $(0.058)$ & -0.049 & $(0.058)$ & $0.147 * *$ & $(0.052)$ \\
\hline Medium(50/250) & 0.060 & $(0.064)$ & 0.001 & $(0.066)$ & $0.184 * *$ & $(0.060)$ \\
\hline Multiplant & -0.004 & $(0.037)$ & -0.058 & $(0.039)$ & $0.117 * *$ & $(0.039)$ \\
\hline New-business & $-0.147 * *$ & $(0.051)$ & $-0.144 * *$ & $(0.055)$ & & \\
\hline UK-owned & $-0.132 *$ & $(0.056)$ & $-0.111^{*}$ & $(0.056)$ & -0.082 & $(0.056)$ \\
\hline ICT user & $0.144^{*}$ & $(0.070)$ & $0.257 * * *$ & 0.071 & $0.319 * * *$ & $(0.045)$ \\
\hline Family-Bus & $-0.077 *$ & $(0.034)$ & 0.102 & $(0.085)$ & $0.150^{*}$ & $(0.061)$ \\
\hline Partnership & $-0.169 * * *$ & $(0.035)$ & $-0.158 * * *$ & $(0.036)$ & -0.050 & $(0.044)$ \\
\hline Sole proprietor & $-0.158^{* *}$ & $(0.053)$ & $-0.170 * * *$ & $(0.048)$ & 0.043 & $(0.056)$ \\
\hline \multicolumn{7}{|c|}{ Owner Characteristics } \\
\hline Age $>46$ & & & & & -0.056 & $(0.033)$ \\
\hline A-lev or GCSE's & 0.071 & $(0.047)$ & 0.068 & $(0.047)$ & -0.017 & $(0.043)$ \\
\hline Higher Degree & $0.092^{*}$ & $(0.041)$ & $0.096^{*}$ & $(0.041)$ & -0.026 & $(0.039)$ \\
\hline \multicolumn{7}{|l|}{ Strategic Decisions } \\
\hline Net-worker & -0.017 & $(0.034)$ & -0.013 & $(0.034)$ & & \\
\hline BS_Reinvest & & & & & $0.089^{*}$ & $(0.041)$ \\
\hline BS_new products & & & & & $0.220 * * *$ & $(0.036)$ \\
\hline \multicolumn{7}{|c|}{ Business Environment } \\
\hline Comp_obst & $0.097 *$ & $(0.039)$ & 0.065 & $(0.040)$ & 0.064 & $(0.037)$ \\
\hline Finance_obst & & & & & 0.014 & $(0.064)$ \\
\hline Industry Effects & Yes & & Yes & & Yes & \\
\hline Regional Effects & Yes & & Yes & & Yes & \\
\hline
\end{tabular}




\begin{tabular}{ll|ll}
\hline Log-L & -1121.89 & -1118.37 & -1747.28 \\
Observations & 2169 & 2169 & 2926 \\
\hline
\end{tabular}

Notes: weighted regression was used with ASBS data. For variable definitions, see Table V. *** significant at 1\%-level, ** significant at 5\%-level, *significant at $10 \%$-level, standard errors in parentheses. Regional and industry dummies included but not reported.

TABLE VIII

Complementarities between Product and Process Innovation and the Export Decision of UK SMEs

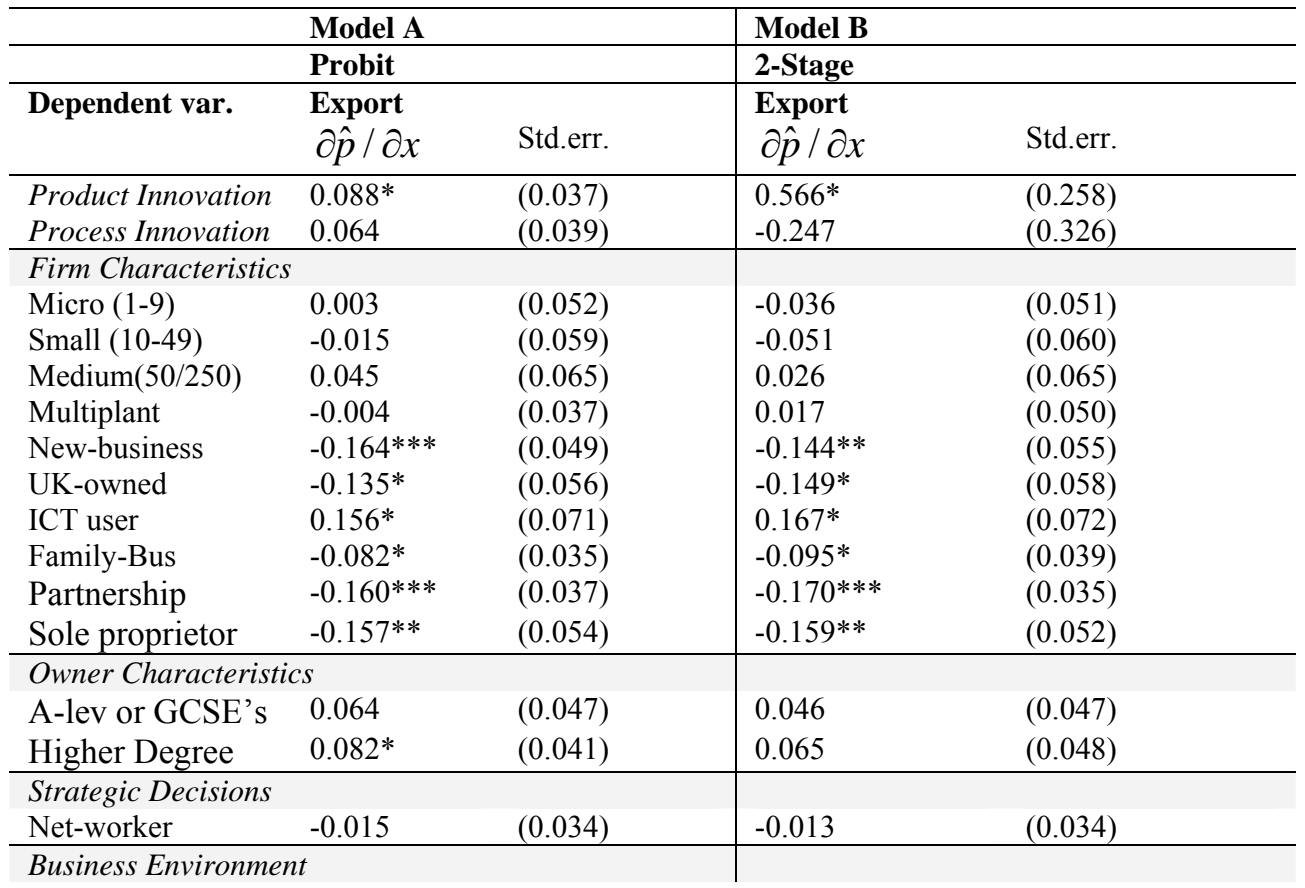




\begin{tabular}{ll|ll} 
Comp_obst & $0.090^{*}$ & $(0.040)$ & $0.102 *$ \\
\hline & & & $(0.041)$ \\
\hline Industry Effects & Yes & Yes \\
Regional Effects & Yes & Yes \\
& & -1127.51 \\
Log-L & -1104.403 & 2184 \\
Observations & 2148 &
\end{tabular}

Notes: weighted regression was used with ASBS data. For variable definitions, see Table V. $* * *$ significant at 1\%-level, ** significant at 5\%-level, * significant at $10 \%$-level, standard errors in parentheses. Regional and industry dummies included but not reported.

TABLE IX:

The Importance of Exporting for Product Innovation

\begin{tabular}{|c|c|c|c|c|c|c|}
\hline & \multicolumn{2}{|l|}{ Model A } & \multicolumn{4}{|l|}{ Model B } \\
\hline & \multicolumn{2}{|l|}{ Probit } & \multicolumn{4}{|c|}{ 2-Stage Estimation } \\
\hline \multirow[t]{2}{*}{ Dependent var. } & \multicolumn{2}{|c|}{ Prod. Innovation } & \multicolumn{2}{|c|}{ Product Innovation } & \multicolumn{2}{|l|}{ Export } \\
\hline & $\partial \hat{p} / \partial x$ & Std.err. & $\partial \hat{p} / \partial x$ & Std.err. & $\partial \hat{p} / \partial x$ & Std.err. \\
\hline Export & $0.102 *$ & $(0.040)$ & 0.457 & $(0.272)$ & & \\
\hline \multicolumn{7}{|c|}{ Firm Characteristics } \\
\hline Micro (1-9) & $0.145 * * *$ & $(0.044)$ & 0.053 & $(0.049)$ & 0.013 & $(0.052)$ \\
\hline Small (10-49) & $0.169 * * *$ & $(0.050)$ & $0.143 * *$ & $(0.054)$ & 0.005 & $(0.058)$ \\
\hline Medium(50/250) & $0.178 * *$ & $(0.057)$ & $0.162 *$ & $(0.065)$ & 0.079 & $(0.063)$ \\
\hline Multiplant & & & & & -0.003 & $(0.037)$ \\
\hline New-business & & & & & $-0.148 * *$ & $(0.052)$ \\
\hline UK-owned & -0.058 & $(0.055)$ & 0.003 & $(0.066)$ & $-0.150 * *$ & $(0.056)$ \\
\hline ICT user & & & & & $0.172 *$ & $(0.068)$ \\
\hline Family-Bus & 0.031 & $(0.035)$ & $0.088^{*}$ & $(0.039)$ & $-0.074 *$ & $(0.034)$ \\
\hline Sole proprietor & -0.052 & $(0.052)$ & -0.043 & $(0.066)$ & $-0.171 * * *$ & $(0.035)$ \\
\hline Partnership & 0.028 & $(0.056)$ & 0.089 & $(0.077)$ & $-0.161 * *$ & $(0.052)$ \\
\hline \multicolumn{7}{|c|}{ Owner Characteristics } \\
\hline Age $>46$ & 0.008 & $(0.035)$ & 0.063 & $(0.035)$ & & \\
\hline A-lev or GCSE's & 0.034 & $(0.045)$ & 0.068 & $(0.048)$ & 0.061 & $(0.047)$ \\
\hline Higher Degree & 0.026 & $(0.042)$ & 0.029 & $(0.046)$ & $0.080 *$ & $(0.041)$ \\
\hline \multicolumn{7}{|l|}{ Strategic Decisions } \\
\hline Networker & & & & & -0.023 & $(0.034)$ \\
\hline BS_Reinvest & $0.094 *$ & $(0.041)$ & $0.107 *$ & $(0.043)$ & & \\
\hline $\mathrm{BS}$ new products & $0.249 * * *$ & $(0.036)$ & $0.272 * * *$ & $(0.036)$ & & \\
\hline
\end{tabular}




\begin{tabular}{|c|c|c|c|c|c|c|}
\hline $\begin{array}{l}\text { Comp_obst } \\
\text { Finance_obst }\end{array}$ & -0.051 & $(0.069)$ & -0.058 & $(0.074)$ & $0.103 * * *$ & $(0.027)$ \\
\hline Industry Effects & Yes & & Yes & & Yes & \\
\hline Regional Effects & Yes & & Yes & & Yes & \\
\hline Log-L & -1814.25 & & -1129 & & -1328.7 & \\
\hline Observations & 2911 & & 2163 & & 2163 & \\
\hline
\end{tabular}

Notes: weighted regression was used with ASBS data. For variable definitions, see Table V. $* * *$ significant at $1 \%$-level, $* *$ significant at 5\%-level, *significant at $10 \%$-level, standard errors in parentheses. Regional and industry dummies included but not reported. 